\title{
Modeling a Bioretention Basin and Vegetated Swale with a Trapezoidal Cross Section using SWMM LID Controls
}

\author{
Julia Bond, ${ }^{1}$ Essoyeke Batchabani, ${ }^{1}$ Musandji Fuamba, ${ }^{1}$ David Courchesne, ${ }^{2}$ and Guy Trudel ${ }^{3}$ \\ ${ }^{1}$ Polytechnique University, Montreal, QC, Canada; ${ }^{2}$ EXP Engineering Consulting Firm, Montreal, QC, Canada; ${ }^{3}$ City of Montreal Planning and \\ Major Projects Division, Montreal, QC, Canada.
}

\begin{abstract}
The Low Impact Development (LID) Control module is utilized in the United States Environmental Protection Agency's Stormwater Management Model (USEPA SWMM) to predict the hydraulic performance of a variety of sustainable stormwater technologies. Data collected in 2019 from the monitoring of a pilot project in Montreal was used to verify the ability of the Bioretention LID Control (which assumes a rectangular cross-section) to accurately simulate outflow from a structure with a trapezoidal cross-section. Two types of LID facility were modeled: one releases captured inflow through a perforated underdrain below the soil layer (bioretention basin; BB); and the other is drained at the surface of the soil layer (vegetated swale; VS). Initially, the modeled LID structures were sized identically to the field surface areas. However, it was necessary to change their model representation to account for the non-rectangular shape of the soil layer. In addition, a sensitivity analysis was completed, and the most influential parameters were identified as the conductivity slope and seepage rate. Both the alteration of the LID structure representation and the parametric calibration greatly improved the simulated outflows from the vegetated swale resulting in an increase of the Nash-Sutcliffe efficiency (NSE) coefficient from -0.6 to 0.64 (NSE $>0.5$ is acceptable for hydrologic models according to the literature). The bioretention basin calibration did not prove as successful. The evaluated LID Control module presented better predictive capabilities for the basin with a simpler overall design (VS).
\end{abstract}

\section{Introduction}

Traditional stormwater management methods drain runoff as quickly and efficiently as possible (MDDEFP 2014). However, concerns emerged about the influence of continual runoff and pollutant loading of downstream water bodies. It was established that one of the largest contributors to nonpoint source pollution of estuaries and lakes is the urban runoff generated by regularly occurring storm events which make up $90 \%$ of storms in a year (USEPA 1983). Furthermore, with the rise in urban development and subsequent expansion of impervious areas, stormwater runoff volume has increased, leading to more frequent combined sewer overflows (CSOs) and conveyance system surcharge (Stovin et al. 2013). In order to address these issues, stormwater management has evolved to focus on the control of runoff quantity, groundwater recharge, water quality and stream bank erosion (MDDEFP 2014). Low impact development (LID) ensures a site is designed to behave hydrologically similarly to predevelopment conditions by managing runoff at the source. Structural solutions have been developed as strategies to encourage the infiltration of rainwater into the ground.

The decision to implement any LID structure must consider the particulars of the site which influence their performance (e.g. topography, soil characteristics, utilization of the surrounding land, scale of impervious surfaces and regional rainfall patterns). The reluctance of professionals to implement these solutions without demonstrative proof of their benefits is a direct consequence of the difficulty in their standardization. Local pilot projects are necessary to encourage overall adoption (Eckart et al. 2017; Ewing et al. 2000).

Hydrologic models can be used to understand the benefits of implementing LID measures into the landscape and to predict their capabilities for handling a variety of rainfall events. Modeling LID structures accurately requires the representation of a multitude of processes such as surface runoff, infiltration, soil percolation, drainage and evapotranspiration. The strength of the model depends on the detail of representation of these processes and the methods which connect them (Elliott Trowsdale 2007).

One popular and complex model used for a range of applications is PCSWMM (Rossman 2015), modeling software available through Computational Hydraulics International (CHI); it uses the U.S. Environmental Protection Agency's (USEPA's) SWMM engine. In 2010, the SWMM5 engine (version 5.0.021) was upgraded to allow the modeling of a variety of LID facilities such as bioretention cells, infiltration trenches, permeable pavements, rain barrels,

Bond, Julia, Essoyeke Batchabani, Musandji Fuamba, David Courchesne, and Guy Trudel. 2021. "Modeling a Bioretention Basin and Vegetated Swale with a Trapezoidal Cross Section using SWMM LID Controls." Journal of Water Management Modeling 29: C474. https://doi.org/10.14796/JWMM.C474 (c) CHI 2021. www.chijournal.org ISSN: 2292-6062. 
vegetative swales, rain gardens, green roofs and rooftop disconnections.

Swales are open vegetated channels which convey and drain stormwater runoff (Deletic and Fletcher 2006). Due to a high surface roughness, they reduce peak flow and infiltrate a portion of runoff (Rushton 2001, Fassman and Stokes 2011).

Rain gardens emulate natural watersheds by infiltrating and treating stormwater runoff (DeBusk et al. 2010; PGCo 2007; USEPA 1999b). As a LID solution, they can be utilized for a variety of purposes, namely to attenuate peak flow, minimize runoff volume and pollutant loading, encourage evapotranspiration, reduce stream erosion and replenish groundwater aquifers (Davis 2008; Davis et al. 2009: Dietz 2007; Dietz and Clausen 2005). In cases where the natural soil of the site has limited percolation capacity, a bioretention cell (biocell) can be implemented instead. Their standard design includes a depression in the ground containing an engineered soil material, an assortment of vegetative species, a layer of bark mulch to prevent soil erosion, and an engineered sub-grade containing a gravel bed and a perforated underdrain pipe (Eckart et al. 2017; lowa Stormwater Partnership 2008).

Considering the continually growing interest in implementing these stormwater management practices, research is needed which aids in understanding SWMM's ability to predict their behavior and performance (Niazi et al. 2017). McCutcheon and Wride (2013) modeled two small rain gardens which collected water from a rooftop. The tributary area to LID area ratio was 5:1. The performance of the basins was assessed based on the volume of water which had overflowed from the rain gardens. Results depicted a good alignment between observed and simulated overflows for both long term and single event analysis. Additionally, the results were compared to a previous study completed in 2012 by the same authors which modeled bioretention basins without field data as a model input. It was established that the inclusion of field data ensured a much better performance of the model (McCutcheon and Wride 2013).

One aspect of modeling LID structures using SWMM which is not discussed in the literature is the influence that a change in the cross sectional area could have on the water balance analysis. The Bioretention Cell LID Control does not require a user input value for the side slope of the layers, instead assuming a rectangular cross section. No other studies were found which discuss whether this assumption impacts the performance of the model.

The main objective of this paper is to evaluate the accuracy of the SWMM simulation results when modeling two different LID structures with trapezoidal cross sections using the Bioretention LID Control.

The outflow from the structures, which were built on a large boulevard in Montreal, was monitored and field tests were performed to characterize the soil type. The steps required to complete the modeling of the LID structures in PCSWMM are:

1. Build an accurate representation of the site in the model.
2. Determine appropriate initial input parameter values.

3. Perform a sensitivity analysis.

4. Determine the optimal values of the most influential parameters (calibration).

5. Validate the calibration with an independent dataset.

6. If necessary, recalibrate and revalidate (using additional independent datasets) until the prescribed performance criteria are met.

\section{Materials and Methods}

\subsection{Site Description and Design of LID Structures}

The site is composed of two different kinds of LID units, bioretention basins (BB) and vegetated swales (VS), which collect runoff from a main boulevard located in eastern Montreal (yellow delineation in Figure 1).

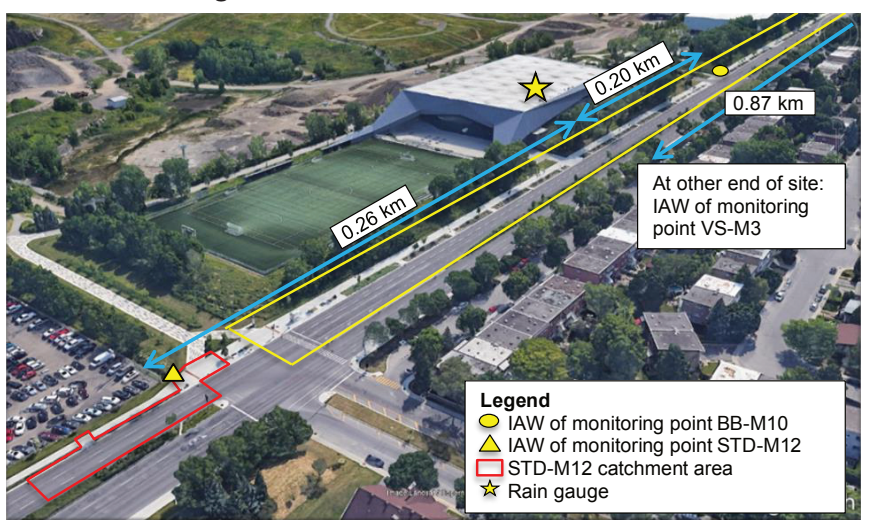

Figure 1 Plan view of site retrieved from Google Earth depicting the location of the monitoring points with respect to the rain gauge (IAW: instrumentation access well; STD: standard).

The design of the catchbasins which collect runoff from the street at the upstream end of each LID cell does not facilitate the installation of monitoring equipment. As a substitute, two alternative runoff collection locations called standard (STD) monitoring points were implemented which were not connected to a LID unit (e.g. STD-M12 delineated in red in Figure 1). These were used to approximate the runoff per unit area of impermeable surface which was multiplied by the impervious catchment area of the respective LID units to obtain the inflow volume.

Instrumentation access wells (IAW) were constructed in the sidewalk to intersect the runoff from the STD sites and the outflow from a set of LID structures and permit the installation of flow monitoring equipment. The two structures considered for this study are a bioretention basin labelled BB-M10 (see Figure 2) and a vegetated swale labelled VS-M3. 


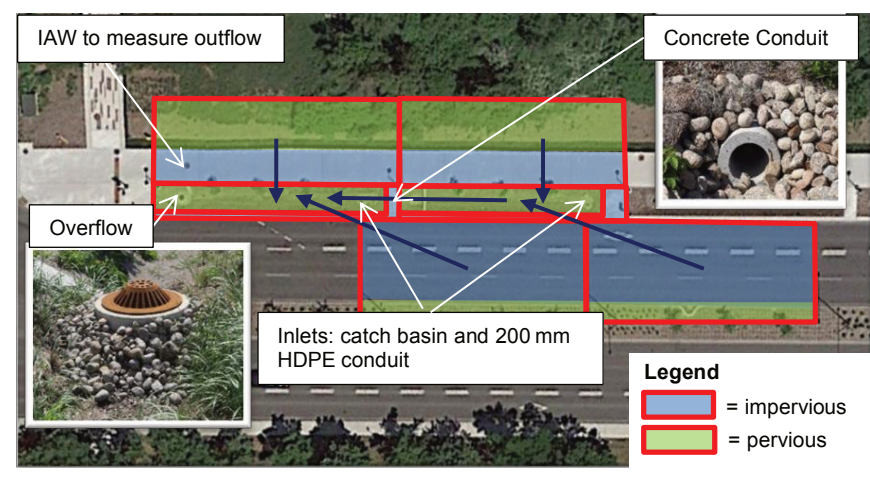

Figure 2 Plan view of bioretention basin-BB-M10 (Google Earth).

A LID unit is composed of 2 to 3 individual cells connected in series by a $250 \mathrm{~mm}$ diameter concrete pipe. Each cell collects water from a section of the street, the adjacent sidewalk ( $1 \%$ slope) and $10 \mathrm{~m}$ of adjacent forested hillside (average slope $55 \%$ ). The runoff from the pervious surfaces was not measured in the field.

Table 1 characterizes the catchment area for both structures. Typically, a LID structure is sized based on a design storm event; in this case the bioretention basin was designed to treat a $25 \mathrm{~mm}$ rainfall event with average duration of $6 \mathrm{~h}$ (representing $90 \%$ of rainfall events or a return period $<2 \mathrm{y}$ ).

Table 1 Characteristics of the LID catchment areas.

\begin{tabular}{lccc}
\hline \multicolumn{1}{c}{ LID type } & Catchment area $\left(\mathrm{m}^{2}\right)$ & \% pervious area & I/P ratio \\
\hline Bioretention basin & 1419 & 40 & $4: 1$ \\
Vegetated swale & 1407 & 39 & $5: 1$ \\
\hline
\end{tabular}

ampervious drainage area to LID surface (I/P) ratio.

In this study, the structures have a deep surface layer (50 $\mathrm{cm}$ compared to the $15 \mathrm{~cm}-22.5 \mathrm{~cm}$ recommended by MDDEFP (2014)); a consequence of the design of the inlet catch basin. The cells were widened to reduce the side slope of the soil layer ensuring plant stability.

The cells (standard size: $3.5 \mathrm{~m} \times 30 \mathrm{~m}, \mathrm{~W} \times \mathrm{L}$ ) have a $0.5 \%-1 \%$ longitudinal slope and collect the street runoff through a rectangular catchbasin and a single $200 \mathrm{~mm}$ diameter HDPE conduit (see Figure 3a-b). Geotechnical tests completed on the in situ soil of the site resulted in low values of saturated hydraulic conductivity (estimated at $2.6 \mathrm{~mm} / \mathrm{h}$ ) and a Unified Soil Classification System (USCS) categorization of silt loam (García-Gaines and Frankenstein2015; MDDEFP 2014). Consequently, a single $20 \mathrm{~cm}$ diameter conventional perforated underdrain (no forced saturation or IWS zone) was installed in the bioretention basins (green conduit in Figure 3f). In this project, the basins are not being used to replenish the water table. An impermeable membrane was installed (on the west side of the cells only) in order to prevent seepage under the adjacent street structure and avoid stability issues.

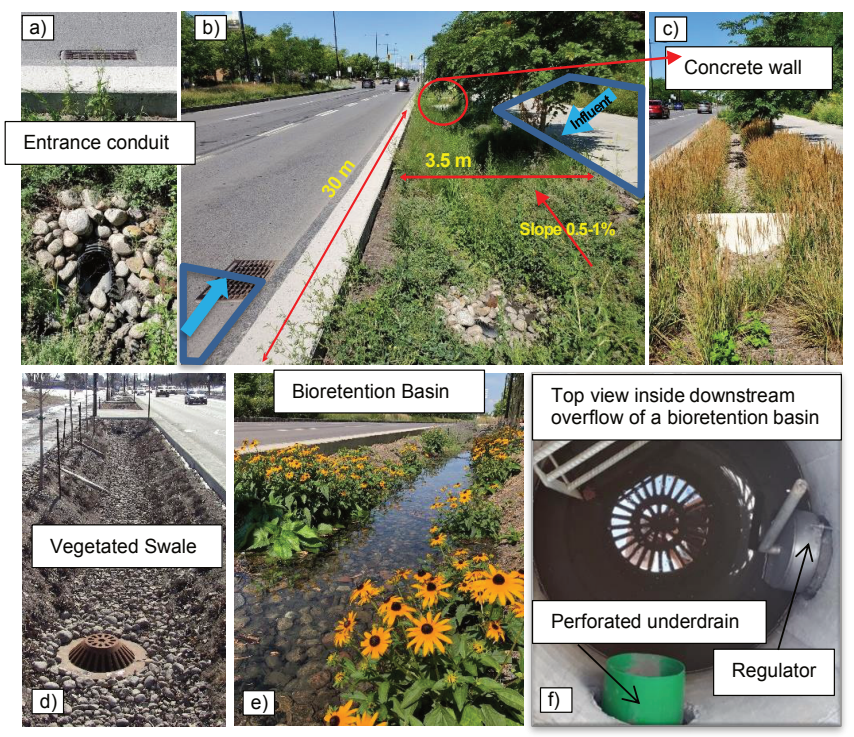

Figure 3 (a) The entrance conduit to a cell; (b) side view of an upstream BB cell; (c) back end view of the concrete wall in an upstream cell; (d) downstream VS cell; (e) BB cell after a rainfall; (f) view of a vortex regulator at the downstream end of a BB.

In addition, the specific basins modeled in this study include flow regulators installed on the conduit linking the downstream drain to the sewer system (Figure 3-f). The flow controls are HYDROVEX VHV vertical vortex regulators by Veolia, model 75 VHV-1 (Veolia Water Technologies 2014). They are designed for a synthetic Chicago event with a 25 y return period resulting in a head above the base of $1.8 \mathrm{~m}$ and a flow of $4.5 \mathrm{~L} / \mathrm{s}$.

The main difference between the two types of LID facilities is the structural components used to provide relief should their infiltration capacity be breached. The bioretention basin is drained from below the soil layer and utilizes a bypass overflow for rarer scenarios. In the upstream cell of the BB, there is a concrete wall blocking the flow to ensure the cell fills up (Figure 3c).

In contrast, the vegetated swale is drained to the sewer line at the surface of the soil layer (Figure $3 \mathrm{~d}$ ). This reduces the water treatment capabilities of the VS.

\subsection{Overview of the SWMM Bioretention Cell LID Control Module}

Each LID Control type has parameters defining its characteristics. The Bioretention Cell LID Control details three distinct layers: the surface layer, the soil layer and the storage layer. It is also possible to model the cell with or without an underground perforated pipe. The movement of water between the layers over time, calculated in $\mathrm{mm} / \mathrm{h}$, is obtained by considering the water balance of each individual layer. Solving this continuum numerically at each runoff time step determines how an inflow hydrograph to the LID unit is converted into some combination of runoff, subsurface 
storage, subsurface drainage and infiltration into the surrounding native soil (Rossman and Huber 2016b).

The Vegetative Swale LID Control does not include the option to provide soil parameters or a seepage rate which was required in this case. Thus, the Bioretention Cell LID Control was also used for the vegetated swale with a value of zero applied to the surface layer, storage layer and the underdrain coefficient. Infiltration through the LID Control is modeled using the GreenAmpt method (Rossman and Huber 2016b).

\section{Soil Percolation Speed}

Darcy's equation (Equation 1) governs the relationship between decreasing soil moisture content and the hydraulic conductivity thus modeling the percolation speed of water through partially saturated soil:

$$
f_{2}=\frac{K_{r s}}{e^{H C O\left(\varnothing_{2}-\theta_{2}\right)}}
$$

where:

$$
\begin{aligned}
f_{2} & =\text { percolation speed }(\mathrm{mm} / \mathrm{h}), \\
K_{r s} & =\text { saturated hydraulic conductivity }(\mathrm{mm} / \mathrm{h}), \\
H C O & =\text { conductivity slope, and } \\
\varnothing_{2}-\theta_{2} & =\text { moisture content deficit }\left(\mathrm{m}^{3} / \mathrm{m}^{3}\right) .
\end{aligned}
$$

\section{Underdrain Flow}

In SWMM, the flow through the underdrain pipe is modeled as a function of the hydraulic head accumulated above its base, as presented in Equation 2. The actual underdrain flow at a given time step will be the lesser of either the amount of water available to the underdrain (percolation rate) or the underdrain unit discharge $q_{3^{\prime}}$ since the latter represents a greatest potential value:

$$
q_{3}=C_{3 D}\left(h_{3}\right)^{\eta_{3 D}}
$$

where:

$q_{3}=$ underdrain unit discharge $\left(\mathrm{m}^{3} / \mathrm{m}^{2} \mathrm{~s}\right)$,

$h_{3}=$ hydraulic head above underdrain invert $(\mathrm{m})$,

$C_{3 D}=$ underdrain discharge coefficient $\left(\mathrm{m}^{-(n 3 D-1)} / \mathrm{s}\right)$, and

$\eta_{3 D}=$ underdrain discharge exponent.

One option for underdrain flow is to use the orifice equation by Torricelli, and a discharge exponent of 0.5 . The underdrain discharge coefficient (units of $\mathrm{m}^{0.5} / \mathrm{s}$ ) can be calculated with Equation 3 for circular drains:

$$
C_{3 D}=504257 \cdot C_{o d}\left(\frac{\pi r^{2}}{A_{L I D}}\right)
$$

where:

$$
\begin{aligned}
A_{\text {LID }} & =\text { footprint area of the LID unit }\left(\mathrm{m}^{2}\right), \\
C_{\text {od }} & =\text { orifice discharge coefficient (unitless), and } \\
r & =\text { radius of drain }(\mathrm{m}) .
\end{aligned}
$$

Another parameter which affects the outflow from the underdrain is the offset height $D_{3 D}$ of the drain from the bottom of the storage layer, which is an element of the physical design of the basin. There is no underdrain flow until the depth of water in the storage layer has reached this offset height (Rossman and Huber 2016b).

\subsection{Representation of the Site in PCSWMM}

\section{Bioretention Basin}

Figure 4 presents a plan view of the modeling of the bioretention basin in PCSWMM with the green surfaces representing the LID cells, pink surfaces the sidewalk and forested hillside, and grey surfaces the boulevard.

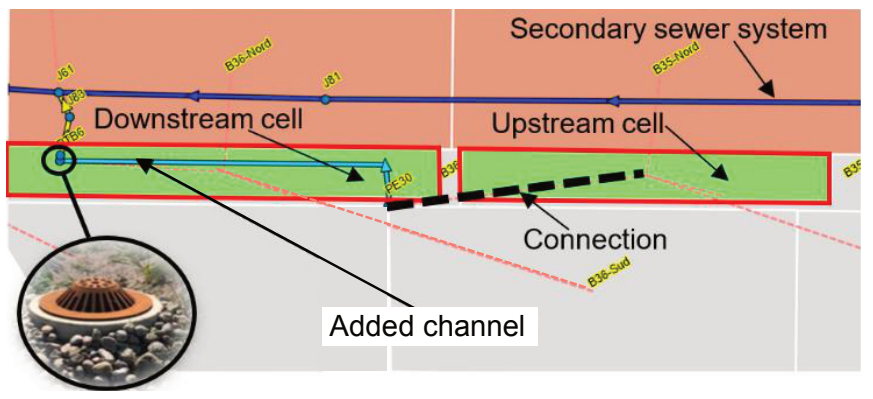

Figure 4 Method used to connect the underdrains of the two bioretention cells in series.

The LID cells were assigned the Bioretention Cell LID Control module (occupies $100 \%$ of subcatchment surface). Since there is no option in PCSWMM to directly connect the underdrains of the two cells, it was necessary to use an overflow arrangement: a rectangular channel (light blue conduit in Figure 4 with $3.5 \mathrm{~m}$ width and $0.19 \mathrm{~m}$ height) was added which connects the upstream cell to the junction at the end of the downstream cell.

As discussed in the introduction, the LID Control object in SWMM assumes a rectangular cross section. A comparison between the actual cross section of the bioretention basin under study and the one assumed by SWMM is presented in Figure 5.

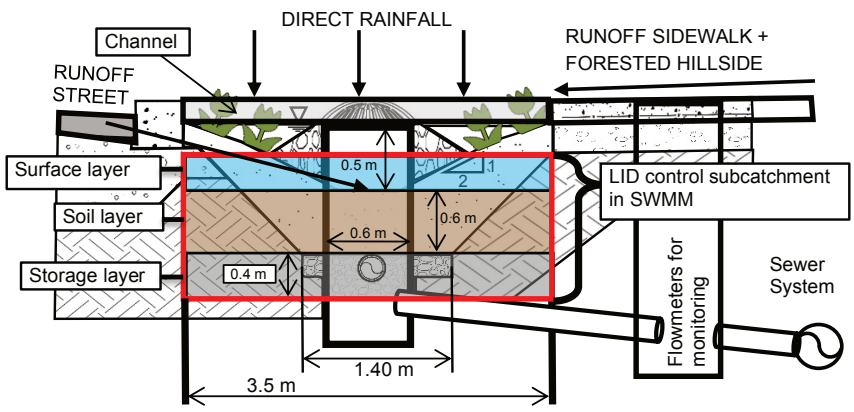

Figure 5 Comparison between bioretention cross sections: in the field and in the model (Les Services EXP Inc. 2019, on behalf of the City of Montreal).

The in situ cross sectional area and volume of the surface, soil and storage layers for the entire bioretention unit are presented in Table 2. These were compared to those obtained for layers with the same depth in PCSWMM (red box in Figure 5 represents the LID control). The total longitudinal length of the BB-M10 structure (both cells combined) is $59 \mathrm{~m}$. 
Table 2 Comparing the volumes of each LID layer in the field and when modeled using the LID Control.

\begin{tabular}{lcc}
\hline \multicolumn{1}{c}{ LID section } & In situ volume $\left(\mathrm{m}^{3}\right)$ & LID Control volume $\left(\mathrm{m}^{3}\right)$ \\
\hline Surface layer & 51 & 103 \\
Soil layer & 118 & 124 \\
Storage layer & 33 & 83 \\
\hline
\end{tabular}

It was deemed necessary to reduce the height of the surface layer by half to prevent an overestimation of the storage potential by the model $\left(51 \mathrm{~m}^{3}\right.$ vs $\left.103 \mathrm{~m}^{3}\right)$.

\section{Vegetated Swale}

Figure 6 presents a plan view of the representation of the vegetated swale in PCSWMM. The LID cells (green surfaces) were assigned the Bioretention Cell LID Control (occupies 100\% of surface). In this case, the surfaces were directly connected since there is no underdrain or storage layer and only surface flow.

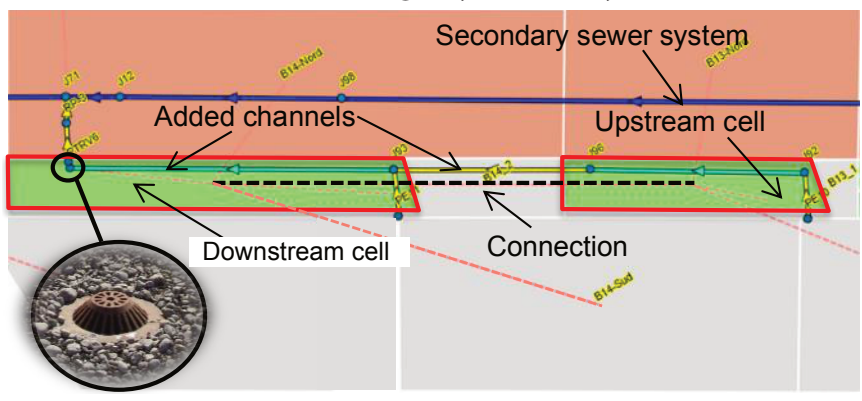

Figure 6 Plan view of model representation of the vegetated swale.

If a large storm were to overflow the exit junction of the VS, the runoff would backup and accumulate in the basin bowl which has a depth of $0.5 \mathrm{~m}$. The likelihood of this occurring is increased by the presence of a regulator which was modeled as an outlet object and designated with the rating curve obtained from the manufacturer. In order to ensure this backwater is stored, a trapezoidal channel, represented by the conduits modeled above the LID cells in Figure 6, was connected to the junction at the exit of the basin. Figure 7 depicts a profile view of this design.

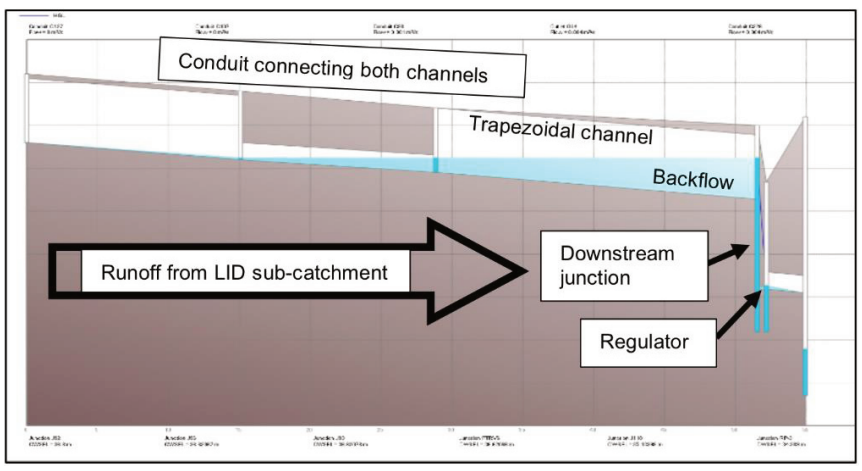

Figure 7 Profile view of the vegetated swale structure in PCSWMM.
The LID Control of the VS only includes the $0.6 \mathrm{~m}$ deep soil layer (berm height and underdrain coefficient set to zero). The storage layer was given a very small depth $(0.00001 \mathrm{~m})$ to ensure a seepage rate.

\section{Standard Monitoring Site (Direct Street Connection)}

The monitoring site collecting water directly from the street (STD-M12) was modeled by routing the runoff from the impervious subcatchment to a junction representing the street drain. This junction was connected to a second junction (where the flow data was measured) via a $200 \mathrm{~mm}$ conduit with a Manning coefficient of 0.013 , which is typically used for aged PVC pipes (Brière 2007).

\subsection{Input Field Data}

In 2019, precipitation data was collected for a total of 47 events at a time-step of 10 min using a Vantage Pro Weather Station; 7 of these events had a recurrence $>2$ y (determined from local HDF curves; Mailhot and Talbot (2012)). Only storm events with a depth $\geq 1 \mathrm{~mm}$ were included. Discrete storm events were separated by a minimum of $3 \mathrm{~h}$ without rainfall prior to their occurrence. Daily maximum and minimum temperature data obtained from the same weather station were incorporated in the climatology section of the model through a climate file.

A compound weir, which combines a $90^{\circ} \mathrm{v}$ notch and a rectangular weir section, was fabricated inhouse and calibrated in the hydraulics laboratory at Polytechnique Montreal University. It was installed inside the IAW, on the downstream end of the conduit collecting either outflow from a basin (in the case of a LID unit) or runoff from the street (in the case of an STD point). A Teledyne ISCO 2150 flow module (Teledyne ISCO 2016), equipped with a pressure transducer, measured the outflow height at a distance $4 \cdot H_{\max }$ behind the weir (2 min time step). Herein, $H_{\max }$ is the height between the notch and the bottom crest of the rectangular section (the goal is to be outside the drawdown zone as stipulated in ASTM D5242-92 (2013)). The measured and simulated flow hydrographs passing through the conduit were compared to assess the accuracy of the model (Figure 8).

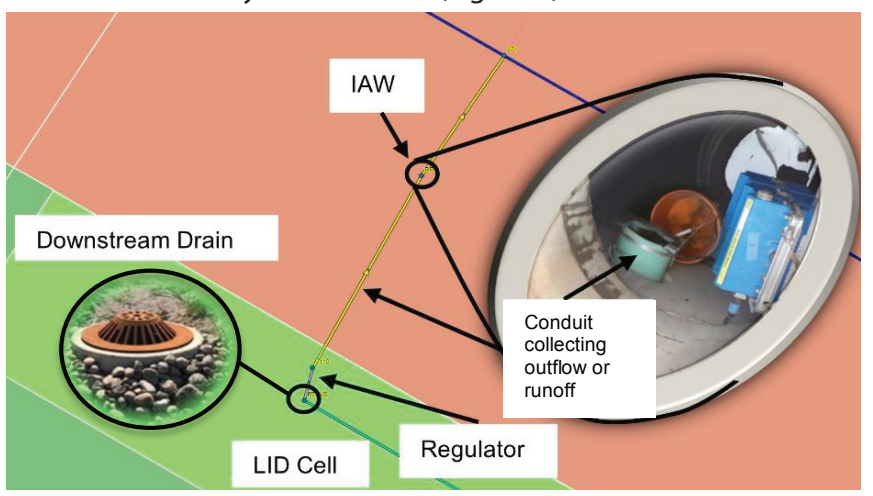

Figure 8 The location of measured outflow data within the PCSWMM model. 
The measurement error of the Teledyne ISCO probe height reading according to the manufacturer datasheet is $0.008 \mathrm{~m} / \mathrm{m}$ (Teledyne ISCO 2016). The resulting flow error ( \pm ) is obtained by applying the error propagation equations (WCI Physics n.d.). When combined with the standard error on the $y$ value of the calibration curves, obtained using the LINEST function in Microsoft Excel, the total outflow volume error is obtained. For example, an event occurring May 23 yielded $584 \mathrm{~L}$ of outflow (for the bioretention basin) with a calculated error of only $\pm 0.96 \mathrm{~L}(0.1 \%)$, which seems very low. Realistically, there are several other sources of errors which are difficult to quantify which would result in a larger error.

The error management actions taken during this project include removing debris from behind the weirs, verifying the calibration of the probe, validating the rainfall data using other rain gauges (located close to the site) and a verification of the laboratory-derived calibration curves in the field.

An issue which occurred during data processing involved the choice of the threshold value to be subtracted from the total height measured by the probe. Theoretically, the threshold should stay constant since it is the physical distance between the bottom of the conduit and the bottom of the v-notch section of the weir. However, at the control site STD-M12, the water level did not stabilize between certain events even after the weir was verified for leaks. Additionally, using the physical threshold value resulted in an unrealistic total volume. For these cases the runoff was calculated using the Rational Method with a value of 0.9 for the runoff coefficient. The selection of the threshold value is important since a small variation (as low as $1 \mathrm{~mm}$ ) can result in a large variation in the calculated volume (of up to $5000 \mathrm{~L}$ ), depending on the event. This is due to the cumulative nature of the calculation (integral over hours of outflow).

There were cases where the measured heights were larger than the diameter of the conduit indicating conduit surcharge. This only occurred at the STD control point. The Rational Method was used for these cases as well.

A HOBOnet soil moisture sensor was installed a third of the way up the side slope of the soil in the center of the upstream cell of each structure. The media was characterized through particle size analysis and evaluated with the Unified Soil Classification System (García-Gaines and Frankenstein 2015). Table 3 presents details on the media composition of the VS and BB.

Table 3 Proportion of gravel, sand and fines in the LID media.

\begin{tabular}{lccc}
\hline \multicolumn{1}{c}{ LID structure } & Gravel (\%) & Sand (\%) & Fines (\%) \\
\hline Bioretention Basin & 0.5 & 74 & 25.5 \\
Vegetated Swale & 0.6 & 81.7 & 17.7 \\
\hline
\end{tabular}

\subsection{Parameter Estimation}

The parameter values used in the initial uncalibrated model were chosen based on the literature, field data or software default values. They are presented in Tables 4 and 5.

Table 4 PCSWMM parameter values used in the uncalibrated model for the general subcatchments.

\begin{tabular}{|c|c|c|}
\hline Parameters & \begin{tabular}{l}
\multicolumn{2}{c}{ Value } \\
Forested \\
hillside + \\
sidewalk
\end{tabular} & Source \\
\hline Manning coefficient-impervious & 0.01 & \multirow{4}{*}{ James et al. (2011) } \\
\hline Manning coefficient-pervious & 0.4 & \\
\hline D store imperv (mm) & 1 & \\
\hline D store perv (mm) & 10 & \\
\hline Zero imperv (\%) & $25 \%$ & Default \\
\hline Infiltration model & Green-Ampt & - \\
\hline Suction head (mm) & 166.8 & USCS soil classification: silt loam; \\
\hline Conductivity (mm/h) & 2.6 & conductivity was measured in the field; \\
\hline Moisture deficit & 0.501 & $\begin{array}{l}\text { suction head and moisture deficit were } \\
\text { taken from the literature. } \\
\text { (MDDEFP 2014) }\end{array}$ \\
\hline
\end{tabular}

Table 5 PCWMM parameter values used in the uncalibrated model for the LID Control for both basin types.

\begin{tabular}{|c|c|c|c|}
\hline \multirow{2}{*}{ Parameters } & \multicolumn{2}{|c|}{ Value } & \multirow{2}{*}{ Source } \\
\hline & VS & $\mathrm{BB}$ & \\
\hline \multicolumn{4}{|l|}{ Surface Layer } \\
\hline Berm height (mm) & 0 & 250 & Design of basins \\
\hline Vegetation volume (fraction) & \multicolumn{2}{|c|}{0.1} & lamecot al \\
\hline Surface roughness (no units) & \multicolumn{2}{|c|}{0.3} & Jallies el al. (ZUTI) \\
\hline Surface slope (\%) & \multicolumn{2}{|c|}{1.0} & Design of basins \\
\hline \multicolumn{4}{|l|}{ Soil Layer } \\
\hline Soil thickness (mm) & \multicolumn{2}{|c|}{600} & Design of basins \\
\hline Soil classification & \multicolumn{2}{|c|}{ SM (Silty sand) } & $\begin{array}{l}\text { García-Gaines and Frankenstein } \\
\text { (2015) }\end{array}$ \\
\hline Hydraulic conductivity (mm/h) & \multicolumn{2}{|c|}{91} & Rocman and Huber (2016) \\
\hline Suction head (mm) & \multicolumn{2}{|c|}{50} & 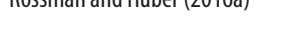 \\
\hline Porosity (fraction) & 0.467 & 0.45 & Field Tests \\
\hline Field capacity (fraction) & \multicolumn{2}{|c|}{0.121} & Rocsman and Huher (2016) \\
\hline Wilting point (fraction) & \multicolumn{2}{|c|}{0.057} & Rossman and ruder (ZO Iod) \\
\hline Conductivity slope (unitless) & \multicolumn{2}{|c|}{44} & Rossman and Huber (2016b) \\
\hline \multicolumn{4}{|l|}{ Storage Layer } \\
\hline Thickness (mm) & 0.00001 & 400 & Design of basins \\
\hline Void ratio (voids/solids) & 0 & 0.54 & Design of basins \\
\hline Seepage rate (mm/h) & \multicolumn{2}{|c|}{2.6} & Field tests \\
\hline Clogging factor & \multicolumn{2}{|c|}{0} & Not considered \\
\hline \multicolumn{4}{|l|}{ Underdrain } \\
\hline Underdrain coefficient & 0 & 152 & Calculated \\
\hline Drain exponent & 0 & 0.5 & Rossman et al. (2016a) \\
\hline Offset height (mm) & 0 & 200 & Design of basins \\
\hline
\end{tabular}

Porosity for the BB was measured as 0.54 in the particle tests; however, the moisture content data showed a plateau at 0.45 . 
The perforated underdrain coefficient of 152 was calculated using Equation 3 and an orifice discharge coefficient $C_{\text {od }}$ of 0.6 as suggested in section 6.5.8 of the SWMM Water Quality Reference Manual (Rossman and Huber 2016b).

The model reporting time step was $1 \mathrm{~min}$; the runoff time step was $6 \mathrm{~h}$ for dry periods and $30 \mathrm{~s}$ during wet periods, as suggested by Rossman and Huber (2016a).

\subsection{Sensitivity Analysis}

The goal of a sensitivity analysis is to understand the influence of the uncertainty of parameter values on the model results. The factor perturbation method involves quantifying the sensitivity of a computed objective function (COF) relative to a change in the parameter value, as given in Equation 4:

$$
\text { Relative Sensitivity }=\frac{\partial C O F / C O F}{\partial p / p}
$$

where:

$$
\begin{aligned}
\text { COF } & =\text { computed objective function, and } \\
p & =\text { parameter value. }
\end{aligned}
$$

COF is a property of the simulated response function under consideration which in this case is the outflow hydrograph (James 2005). Examples of COFs include the total output volume for long term simulations and the peak flow for single event simulations (Peng and Stovin 2017). Herein, the peak flow was assessed by taking the average of the relative peak flow sensitivities calculated for each event.

James (2005) suggests small changes to parameter values to avoid entering nonlinear sensitivity gradients. Thus, a parameter under evaluation was increased and decreased by $25 \%$ while keeping all other parameters constant, as proposed by Jewell et al. (1978) and Rosa et al. (2015). The SRTC tool available in PCSWMM was used to quicken the process.

The sensitivity of the model to evaporation rates was also determined. Although the climate file should be more accurate in capturing the daily variations which can occur in the evaporation rate, this is slightly more complex than simply using monthly rates. The two methods were compared. Additionally, there exists uncertainty in the values whether using a climate file (location and instrumentation error) or average monthly daily evaporation rates. Values of $0 \mathrm{~mm} / \mathrm{d}$ (April), $4.2 \mathrm{~mm} / \mathrm{d}$ (May), $4.6 \mathrm{~mm} / \mathrm{d}$ (June) and $4.6 \mathrm{~mm} / \mathrm{d}$ (July) were obtained directly from Environment Canada (2018) for the years 1981-2010. These were subsequently altered by $25 \%$ and $-25 \%$.

Another aspect to consider is the spatial discretization of the model (Lee et al. 2018). Although the site modeled in this study is quite small compared to an entire watershed, there remained two surfaces to consider for spatial division: the sidewalk (1\% slope) and adjacent forested hillside (average slope $55 \%$ ). The question remained whether to model two surfaces with their own respective parameter values or one surface with a slope of $1 \%$ and proportional percentage imperviousness.

\subsection{Calibration and Validation}

To improve the model predictions, the most influential parameters must be optimized while staying within their realistic range (Peng and Stovin 2017); this describes calibration.

A parameter was considered calibrated either once the error between the two curves (measured and simulated) was acceptable according to the performance metrics or once the range of possible values was exhausted (Rosa et al. 2015).

There are multiple studies and documents that support the idea that in the case of rainfall-runoff models it is significantly more accurate to simulate over the entire time series available for model calibration; thus, a continuous calibration was completed rather than single event based (James 2005, Rosa et al. 2015, Shamsi and Koran 2017).

The calibration was completed manually, and two performance metrics were utilized to assess the model accuracy: the Nash-Sutcliffe efficiency (NSE) coefficient and the relative error (RE).

The NSE coefficient is an objective function used to assess specifically the predictive power of hydrological models (Nash and Sutcliffe 1970). It evaluates the closeness of the simulated data to the measured data against a 1:1 line and can range from negative infinity to 1 . The value of 1 represents a case of null error. A multitude of studies modeling different sized catchment areas as well as those focused on the calibration protocol itself state NSE $>0.5$ qualifies as acceptable for hydrologic models (Peng and Stovin 2017; Burszta-Adamiak and Mrowiec 2013; Zhao et al. 2009; Shamsi 2012; Santhi et al. 2001; Engel et al. 2007; Ramanarayanan et al. 1997).

The relative error refers to the comparative percentage difference between the specified properties of the predicted and observed time series (Zhao et al. 2009). Two properties of the outflow hydrograph were evaluated using global relative volume error (GRVE) and global relative peak error (GRPE). GRVE considers the outflow volume for the entire calibration period. GRPE is the average of the absolute values of RPE for each event and thus does not consider if the peak was reduced or increased. Depending on the event, the error can be positive or negative; simply taking the average would lead to a smaller overall error. The accepted error for both is $<25 \%$ (Fuamba et al. 2019).

The validation of the model involves running the simulation with a separate rainfall data set and assessing the model performance. If the performance metrics are not met, the model requires additional calibration (USEPA 1999a).

\section{Results and Discussion}

Data collected on the site from 2019-04-18 to 2019-07-30 (28 events for a total depth of $434 \mathrm{~mm}$ ) was used for calibration and the data collected between 2019-08-01 and 2019-11-05 was used for validation. The uncalibrated model for both LID structures resulted in complete retention for all medium to small events, whereas outflow was measured in the field for many of them. 
The model predicted outflow to occur only for the largest events. Table 6 presents a characterization of the latter based on total precipitation depth, duration, maximum intensity and antecedent dry days (ADD). The final calibration was focused on events 1 to 5 .

Table 6 Characteristics of the largest rainfall events that occurred between April and November 2019.

\begin{tabular}{|c|c|c|c|c|c|c|c|}
\hline \multirow[t]{2}{*}{ Event \# } & \multirow[t]{2}{*}{$\begin{array}{l}\text { Start Date and Time } \\
\text { (hh:mm) }\end{array}$} & \multirow[t]{2}{*}{$\begin{array}{l}\text { Depth } \\
(\mathrm{mm})\end{array}$} & \multirow[t]{2}{*}{$\begin{array}{l}\text { Duration } \\
\text { (h:min) }\end{array}$} & \multirow[t]{2}{*}{$\begin{array}{l}\text { Avg. Intensity/ } \\
\text { Peak Intensity } \\
(\mathrm{mm} / \mathrm{h})\end{array}$} & \multirow[t]{2}{*}{$A D D$} & \multicolumn{2}{|c|}{$\begin{array}{c}\text { Field } \\
\text { Volumetric } \\
\text { Moisture } \\
\text { Content \% }\end{array}$} \\
\hline & & & & & & (VS) & $(\mathrm{BB})$ \\
\hline \multicolumn{8}{|c|}{ Calibration Period } \\
\hline 1 & 2019-04-18 17:55 & 48.66 & $39: 20$ & $1.24 / 16.46$ & 3.05 & $N A^{a}$ & $\mathrm{NA}^{\mathrm{a}}$ \\
\hline 2 & 2019-05-09 19:35 & 57.12 & $24: 05$ & $2.37 / 28.98$ & 6.29 & $N A^{a}$ & 31.7 \\
\hline 3 & 2019-07-11 7:30 & 34.04 & $3: 40$ & $9.28 / 74.70$ & 4.85 & 29.8 & 30.0 \\
\hline 4 & 2019-07-21 5:50 & 29.97 & $1: 20$ & $22.48 / 97.56$ & 2.70 & 30.4 & 32.2 \\
\hline 5 & 2019-07-30 19:10 & 43.68 & $1: 30$ & $29.12 / 100.56$ & 9.50 & 27.7 & 31.3 \\
\hline \multicolumn{8}{|c|}{ Validation Period } \\
\hline 6 & $2019-10-0114: 45$ & 50.13 & $7: 35$ & $6.61 / 58.11$ & 0.53 & 32.5 & 33.6 \\
\hline 7 & $2019-10-3114: 10$ & 63.15 & $19: 30$ & $3.29 / 19.80$ & 0.38 & 33.3 & 34.0 \\
\hline
\end{tabular}

${ }^{\mathrm{a}} \mathrm{NA}=$ non-available.

The uncalibrated results of the VS presented a $66 \%$ overestimation of the total outflow volume but showed good alignment in time. The peak flow was accurately predicted for the most intense events $(3,4,5)$ indicating that events 1 and 2 contributed to the $64 \%$ GRPE. In the case of the BB, the outflow hydrographs of each event were delayed in time (average $1.3 \mathrm{~h}$ ) with respect to the measured outflow. The predicted outflow volume and peak flow for all events except for event 4 were overestimated (107\% GRVE and 159\% GRPE). When comparing the behavior of both structures, in general, the outflow from the BB was smaller and arrived later than the VS. This is primarily due to the additional storage that is provided as a result of the $400 \mathrm{~mm}$ storage layer and the fact that it must be filled to $200 \mathrm{~mm}$ before outflow occurs.

\subsection{Alteration to the Representation of the Struc- tures in PCSWMM}

An element which could explain the overestimation of the predicted outflow volume is an incorrect representation of the LID structures in the model. It was hypothesized that it was necessary to consider not only the volume of the soil layer but also its shape. SWMM models the soil layer as a rectangle whereas its cross section in the field has an irregular shape. Practically, the runoff from the sidewalk flows through the layer of soil which follows a 2:1 slope in which the vegetation is planted (topsoil highlighted yellow in Figure 9) prior to percolating further down into the main $0.6 \mathrm{~m}$ deep soil layer. In order to more accurately capture the shape of the soil layer, it was split into two different modeling elements as shown in Figure 9.

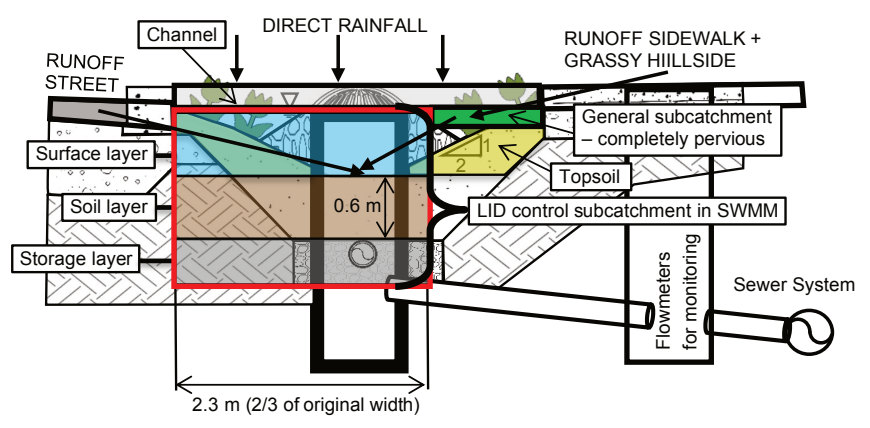

Figure 9 Cross sectional view of the altered BB model representation and LID Control width (Les Services EXP Inc. (2019), on behalf of the City of Montreal).

The bottom soil is represented by the main LID Control subcatchment modeling element (brown surface in Figure 9). The width of the LID subcatchment was adjusted to ensure that the modeled soil volume matched the actual volume $\left(\sim 70 \mathrm{~m}^{3}\right)$. The berm height of the surface layer was returned to its field value of $500 \mathrm{~mm}$ since the potential surface volume was no longer being overestimated. As for the topsoil, two cases were considered for its representation. The first was using a LID Control subcatchment where the soil layer was parameterized identically to the main layer. Its depth was chosen to equate its volume with that of the topsoil. The second used a general pervious subcatchment (no LID Control) which employed the Green-Ampt infiltration method. The latter (represented in plan view in Figure 10) was conserved since it yielded the best results.

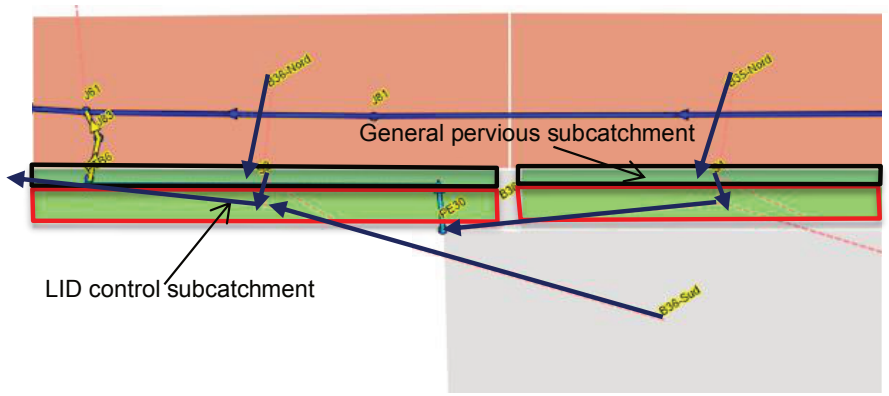

Figure 10 Plan view of the alterations made to the representation of the LID facilities in PCSWMM.

The general subcatchment (darker green surface in Figure 10) was modeled as completely pervious with infiltration parameters matching those input into the main LID soil layer ( $\mathrm{K}=91$ $\mathrm{mm} / \mathrm{h}$, suction head $=50 \mathrm{~mm}$ and initial moisture deficit $=0.467$ ). These alterations were made to both the vegetated swale and the bioretention basin which improved the NSE values from -0.6 to 0.1 (VS) and from -2.73 to $-1.39(\mathrm{BB})$.

\subsection{Sensitivity Analysis}

In order to complete the parametric calibration of the model, it is necessary to identify the most influential parameters. Table 7 presents the sensitivity of the model to a change in the constant monthly daily evaporation rates, the infiltration parameters of the 
general subcatchments, Dstore, zero percent impervious and the most pertinent LID Control module parameters.

Table 7 Relative sensitivity of the total effluent volume (entire calibration period) and peak flow (average including all events) to a change of $25 \%$ and $-25 \%$ in parameter values.

\begin{tabular}{|c|c|c|c|c|c|c|c|c|}
\hline \multirow{3}{*}{$\begin{array}{l}\text { Basin } \\
\% \text { change }\end{array}$} & \multicolumn{4}{|c|}{ VS } & \multicolumn{4}{|c|}{$\mathrm{BB}$} \\
\hline & \multicolumn{2}{|c|}{$-25 \%$} & \multicolumn{2}{|c|}{$+25 \%$} & \multicolumn{2}{|c|}{$-25 \%$} & \multicolumn{2}{|c|}{$+25 \%$} \\
\hline & Total & Peak & Total & Peak & Total & Peak & Total & Peak \\
\hline Parameter & $\begin{array}{l}\text { Vol. } \\
(\%)\end{array}$ & $\begin{array}{l}\text { Flow } \\
(\%)\end{array}$ & $\begin{array}{l}\text { Vol. } \\
\text { (\%) }\end{array}$ & $\begin{array}{c}\text { Flow } \\
(\%)\end{array}$ & $\begin{array}{l}\text { Vol. } \\
\text { (\%) }\end{array}$ & $\begin{array}{c}\text { Flow } \\
(\%)\end{array}$ & $\begin{array}{l}\text { Vol. } \\
(\%)\end{array}$ & $\begin{array}{l}\text { Flow } \\
(\%)\end{array}$ \\
\hline Evaporation rates $(\mathrm{mm} / \mathrm{h})$ & -31 & -2 & -19 & -2 & -45 & -48 & -21 & -47 \\
\hline \multicolumn{9}{|l|}{ General subcatchments } \\
\hline Dstore (mm) & -15 & -16 & -10 & -21 & -17 & -58 & -18 & -33 \\
\hline Zero percent imperv. (\%) & 2 & 0 & 2 & 0 & 1 & -1 & 2 & 1 \\
\hline \multirow{3}{*}{ 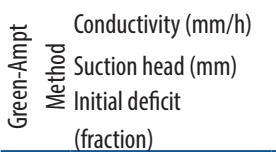 } & -21 & -21 & -11 & -11 & -21 & -30 & -19 & -21 \\
\hline & -8 & -9 & -8 & -5 & -6 & -10 & -12 & -8 \\
\hline & -8 & -12 & -10 & -7 & -6 & -13 & -15 & -10 \\
\hline \multicolumn{9}{|l|}{ LID Control } \\
\hline Manning coefficient & 0 & -15 & 0 & -13 & 0 & 0 & 0 & 0 \\
\hline Surface slope (\%) & 0 & 9 & 0 & 6 & 0 & 0 & 0 & 0 \\
\hline Porosity (fraction) & 0 & 1 & 0 & 0 & 0 & 0 & 1 & 0 \\
\hline Hydraulic conductivity (mm/h) & -10 & -2 & -8 & -9 & 0 & 31 & 1 & 42 \\
\hline Conductivity slope & 59 & 93 & 42 & 25 & 33 & 124 & 22 & 102 \\
\hline Seepage rate (mm/h) & -31 & -14 & -14 & -13 & -29 & -47 & -16 & -37 \\
\hline
\end{tabular}

The most influential of the parameters characterizing the infiltration rate of the pervious catchment areas is conductivity. The height of runoff removed by the general catchment surfaces (Dstore) also has a primary effect on peak and volume. LID Control parameters for which the relative sensitivity was zero, namely, suction head, vegetation fraction, wilting point and field capacity were not included in Table 7. The most influential are the hydraulic conductivity, conductivity slope and seepage rate.

Additionally, separation of the sidewalk and forested hillside surfaces did not result in any significant change in the outflow. In order to simplify the representation of the site in the model, a single subcatchment with a $1 \%$ slope was conserved.

\subsection{Calibration Catchment Area Parameters}

\section{Impervious Surface Parameters}

The accuracy of the parameter values chosen for the impervious surfaces was assessed by comparing the predicted and measured runoff at the STD site. Figure 11 presents the volumetric runoff data (per $\mathrm{m}^{2}$ of impervious catchment) collected directly from the street (site STD-M12) for all events (from 2019-04-18 to 2019-0801). Additionally, a comparison is made between the simulated and observed outflow hydrographs for two significant events.

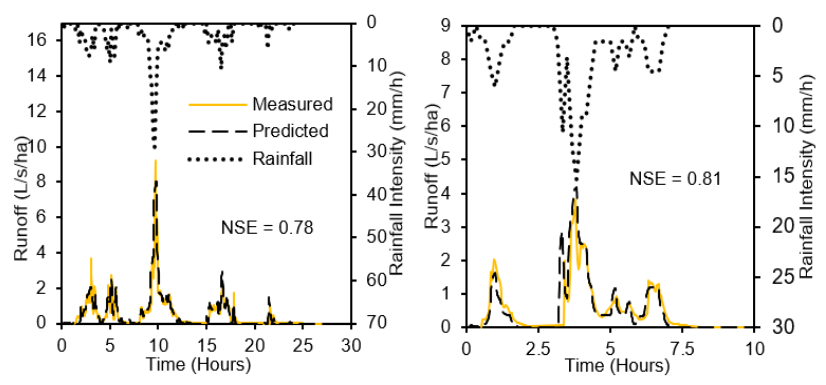

(a)

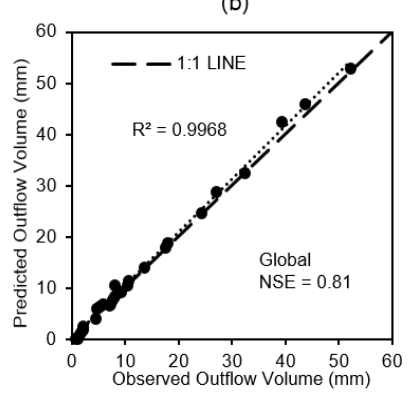

(c)

Figure 11 (a and b) Simulated and measured outflow (per hectare of impervious catchment area) for two major events and (c) volumetric data (per $\mathrm{m}^{2}$ of impervious catchment area) for all rainfall events from April to July 2019 at site STD-M12 (catchment area is $634 \mathrm{~m}^{2}$ ).

The event represented in Figure 11 (a) occurred on 201905-10, has a total depth of $57.1 \mathrm{~mm}$ and lasted $24.1 \mathrm{~h}$ for an average intensity of $2.37 \mathrm{~mm} / \mathrm{h}$. The event represented in Figure 11 (b) occurred on 2019-06-10, has a total depth of $20.25 \mathrm{~mm}$ and lasted $6.8 \mathrm{~h}$ for an average intensity of $2.96 \mathrm{~mm} / \mathrm{h}$. There is a very close alignment between observed and simulated data as reflected in the goodness-of-fit metrics. This validates the predicted runoff from impervious surfaces in the model to which were applied the same parameter values as the STD-M12 subcatchment resulting in an average runoff coefficient of 0.9.

It is important to note that the control site STD-M12 is located at a low point where the street slope changes direction. This differs from the LID cell catchment areas where the street follows a continuous slope. It is more likely that in the latter case some of the runoff by-passes the street grate during very large storms. This could explain an overestimation of the outflow by the model under certain circumstances.

The coarseness of the rainfall data timestep (10 $\mathrm{min}$ ) could reduce the accuracy of the model in terms of the timing and magnitude of the peak flows. This is due to possible variations in the rainfall intensity which were not captured during the $10 \mathrm{~min}$. This uncertainty could affect the validity of the values chosen for parameters which influence peak flow. 


\section{Pervious Surface Parameters}

The forested hillside surface contributes to the uncertainty in the inflow volume. Of the three parameters characterizing the infiltration method for this catchment area, the conductivity has the most influence on the model (Table 7). An uncertainty of $100 \%$ was assumed since in the literature, when choosing infiltration parameter values based solely on soil characterization, there can be a significant variability in the suggested value. This is due to soil heterogeneity. Additionally, the borehole tests completed on the site were not taken adjacent to the structures under study. The original conductivity value of $2.6 \mathrm{~mm} / \mathrm{h}$ was increased to 5.6 $\mathrm{mm} / \mathrm{h}$ for both structures in order to reduce the runoff from the pervious catchment.

\subsection{Calibration LID Control Parameters}

The previous alterations still resulted in an overestimation of the outflow. It can be further decreased by calibrating the conductivity slope ( $\mathrm{HCO}$ ), an influential parameter which characterizes the decrease in the soil conductivity as a function of moisture content. The soil percolation speed described by Equation 1 (a natural exponential function) is a function of $\mathrm{HCO}$.

Figure 12 compares simulation results with different $\mathrm{HCO}$ values. For both the bioretention basin and vegetated swale, a higher $\mathrm{HCO}$ indicates a higher rate of exponential decrease in the unsaturated conductivity which reduces the percolation speed during dry periods. Prior to a rainfall event the storage capacity of the soil will be reduced due to a larger initial moisture content since less water was able to drain. This increases the outflow volume and peak flow. Furthermore, the rise in conductivity during an event will also be exponentially larger. In the case of the BB, this will cause the storage layer to be filled more rapidly and thus the outflow will exit earlier (the peak will also be larger since there is less detention of the flow). The difference in the case of the VS is that the percolation rate is controlled by the exfiltration rate since there is no underdrain (it cannot exceed $2.6 \mathrm{~mm} / \mathrm{h}$ ).

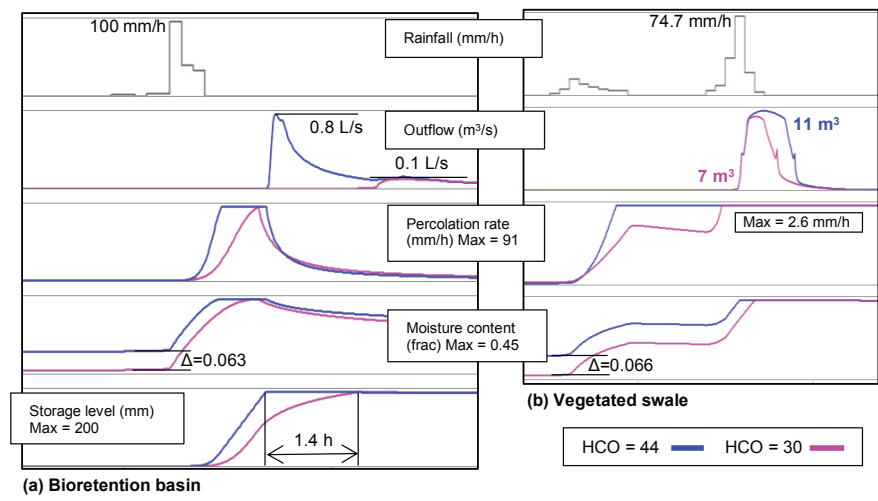

Figure 12 Effect of change in the conductivity slope (HCO) parameter value on the main LID Control elements and the outflow from (a) the bioretention basin (for event 4) and (b) the vegetated swale (for event 3 ).
Rossman and Huber (2016b) suggest a range of 30-55 for the HCO for bioretention structures. The minimum value was tested initially and proved beneficial to both structures; however, in the case of the vegetated swale this led to an underestimation of the outflow. Thus the value of 30 was kept for the BB but a value of 35 was used for the VS.

Additional parameters which may improve the calibration include the soil conductivity (Rossman and Huber (2016b) suggest a range of $50-140 \mathrm{~mm} / \mathrm{h}$ ) and the seepage rate. In the case of VS, the performance metric values were already acceptable; however, increasing the saturated conductivity $\left(K_{s}\right)$ from $91 \mathrm{~mm} / \mathrm{h}$ to $120 \mathrm{~mm} / \mathrm{h}$ improved the overall NSE from 0.581 to 0.642 (1 event was improved). This value was also applied to the pervious subcatchment which represents the topsoil (see Figure 9).

The BB calibration demonstrated significant variations in the results depending on the rainfall event. Thus, increasing the seepage rate did not have homogeneous effects and did not benefit the system. $K_{s}$ did not have an influence on the results.

\subsection{Validation}

The model was validated using the data collected from 2019-0801 to 2019-11-05 (19 events for a total of $370 \mathrm{~mm}$ and 4 significant rainfall events).The validation was only completed for the vegetated swale since the bioretention basin was not successfully calibrated.

The validation indicated the calibration was successful with global NSE 0.642, GRVE 16\% and GRPE 33\%. Specific results for two rainfall events are presented in Table 8.

Table 8 Performance results for two events considered in the validation of the vegetated swale calibration.

\begin{tabular}{lcc}
\hline \multicolumn{1}{c}{ Descriptive Metric } & Event October 1 (Table 6) & Event 0ctober 31 (Table 6) \\
\hline NSE & 0.68 & 0.83 \\
Measured outflow volume $(\mathrm{mm})$ & 24.79 & 32.38 \\
Simulated outflow volume $^{\mathrm{a}}(\mathrm{mm})$ & 26.19 & 32.15 \\
\% error outflow volume & -6 & 1 \\
Measured peak flow ${ }^{\mathrm{b}}(\mathrm{L} / \mathrm{s} / \mathrm{ha})$ & 5.76 & 4.42 \\
Simulated peak flow ${ }^{\mathrm{b}}(\mathrm{L} / \mathrm{s} / \mathrm{ha})$ & 4.10 & 3.05 \\
\% error peak flow & 29 & 31 \\
${ }^{2}$ Volume per m ${ }^{2}$ of impervious catchment; & & \\
${ }^{b}$ Flow per hectare of impervious catchment. & &
\end{tabular}

\subsection{Evaluation of the Calibration}

\section{Long Term Continuous Evaluation}

The improvement in the performance metrics of the model due to the change in the representation of the LID facilities and the parameters is presented in Table 9. 
Table 9 Global performance metrics for the bioretention basin and vegetated swale.

\begin{tabular}{|c|c|c|c|c|c|c|c|c|c|c|}
\hline \multirow{3}{*}{ Site } & \multirow{3}{*}{$\begin{array}{l}\text { Total measured } \\
\text { outflow volume } \\
\text { per } \mathrm{m}^{2} \text { impervi- } \\
\text { ous catchment } \\
(\mathrm{mm})\end{array}$} & \multirow[b]{3}{*}{$\begin{array}{l}\text { Un- } \\
\text { calib. }\end{array}$} & \multirow{2}{*}{\multicolumn{2}{|c|}{ NSE }} & \multicolumn{6}{|c|}{ Global Relative Error } \\
\hline & & & & & \multicolumn{3}{|c|}{ Volume $^{\mathrm{a}}(\%)$} & \multicolumn{3}{|c|}{$\operatorname{Peak}^{\mathrm{b}}(\%)$} \\
\hline & & & $\begin{array}{l}\text { Alteration } \\
\text { to LID } \\
\text { surface }\end{array}$ & $\begin{array}{l}\text { Final } \\
\text { Calib. }\end{array}$ & $\begin{array}{l}\text { Un- } \\
\text { calib. }\end{array}$ & $\begin{array}{l}\text { Alteration } \\
\text { to LID } \\
\text { surface }\end{array}$ & $\begin{array}{l}\text { Final } \\
\text { Calib. }\end{array}$ & $\begin{array}{l}\text { Un- } \\
\text { calib. }\end{array}$ & $\begin{array}{l}\text { Alteration } \\
\text { to LID } \\
\text { surface }\end{array}$ & $\begin{array}{l}\text { Final } \\
\text { Calib. }\end{array}$ \\
\hline VS & 89.96 & -0.60 & 0.10 & 0.64 & -66 & -19 & 14 & 64 & 37 & 27 \\
\hline BB & 40.09 & -2.73 & -1.39 & -0.34 & -107 & -52 & 3 & 159 & 106 & 85 \\
\hline
\end{tabular}

${ }^{b}$ The $\%$ peak error is the average of the absolute value of the RPE for each event.

The overall capability of the model to predict the outflow from the vegetated swale was improved through the calibration and deemed acceptable (NSE >0.5). The model slightly underestimates (14\%) the total outflow. GRPE was significantly improved with the change in the LID surface and the parametric calibration reduced it further by $10 \%$.

Although the change to the LID representation and parameter values improved the global NSE for the bioretention basin, it still presented a negative value. GRVE was reduced by $49 \%$ with the change to the parameter values. Although the error is small, it is not representative of the alignment of the hydrographs and their forms which prove to be incorrectly predicted by the model for certain events. As for the peak flow error, it is significantly larger than the desired threshold.

\section{Short Term Event-Based Evaluation}

Global performance evaluation metrics should not be completely depended upon to understand the accuracy of a model. A more detailed evaluation of the calibration involves focusing on the performance at the level of individual events. Figure 13 compares the measured and predicted outflow volume for each event monitored. The model predicted no outflow for almost all the events with a measured outflow volume $<5 \mathrm{~m}^{3}$. This bias in the predicted outflow volume results in GRVE indicating an underestimation of the total volume despite half the major events being overestimated.
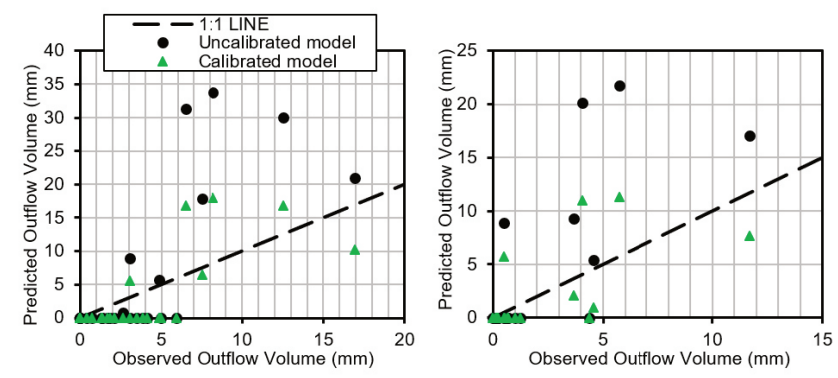

Figure 13 Change in outflow volume (per $\mathrm{m}^{2}$ of impervious catchment area) due to model calibration for all events from April 18 to July 30: (left) vegetated swale; (right) bioretention basin.

Furthermore, the performance evaluation should not focus solely on the outflow but on what is going on inside the LID Control. For instance, the initial moisture content of the soil influences the storage capacity of the LID structure. To assess this further, two events with very different characteristics were considered, event 2 (57 $\mathrm{mm}$ in $24 \mathrm{~h}$ ) and event 5 (44 $\mathrm{mm}$ in $1.5 \mathrm{~h}$ ), shown in Table 6.

In the case of the vegetated swale, outflow will be predicted by the model under two circumstances: when the soil is completely saturated (leading to surface runoff) as demonstrated in Figure 14; and when the inflow rate exceeds the infiltration rate in the top part of the soil layer (even when overall the soil is not saturated) as in Figure 15. The latter presents the behavior of the VS under a high intensity event, event 5 , which had $44 \mathrm{~mm}$ of rain in $1.5 \mathrm{~h}$.

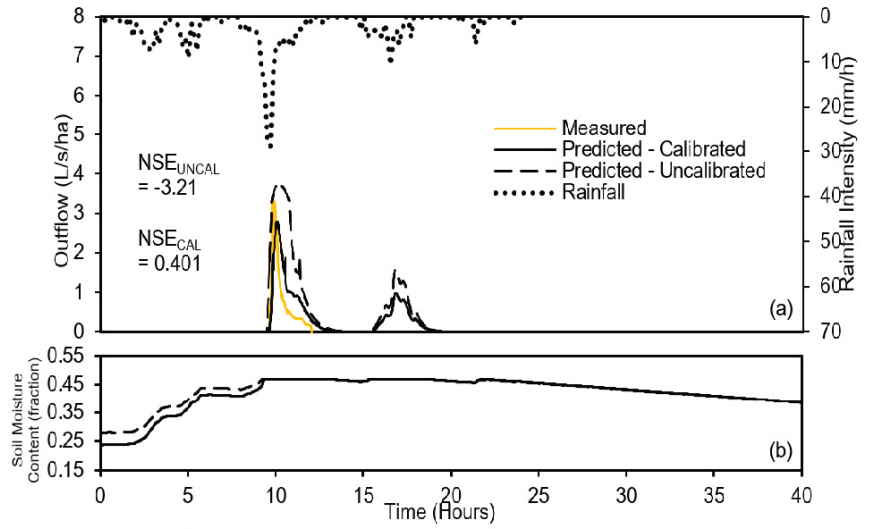

Figure 14 Comparison between (a) measured and simulated outflow hydrographs (L/s/ha of impervious catchment) and (b) measured and simulated soil moisture content in the vegetated swale for significant event 2 ; note: the field moisture data are not available for this event.

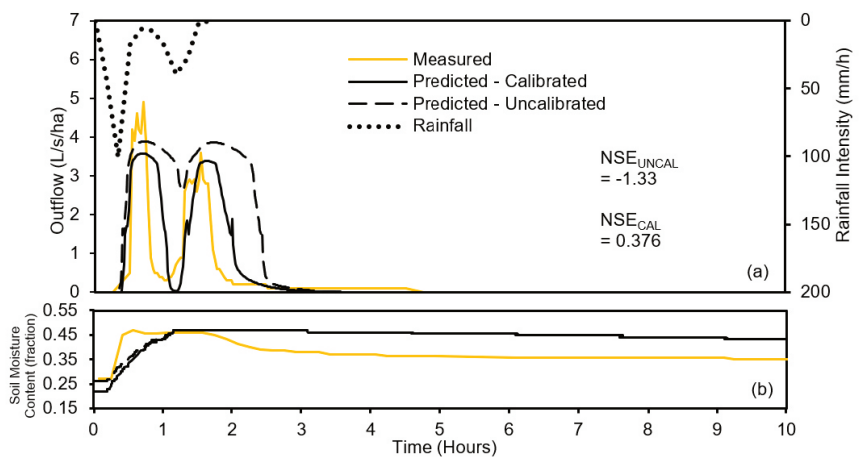

Figure 15 Comparison between (a) measured and simulated outflow hydrographs (L/s/ha of impervious catchment) and (b) measured and simulated soil moisture content in the vegetated swale for significant event 5 .

The soil moisture content probe is located a third of the way up the sloped side of the soil layer near the surface. Thus when there is accumulation of water in the bowl of the structure, as there was for the intense event 5 , the probe will be inundated. This saturation of the soil will disappear quickly immediately after the event as the surface water level in the cell is drained. This 
could explain the sudden drop in the field moisture content right after the rainfall. From this point onward, the moisture content reading is mostly affected by evaporation. Thus, after $24 \mathrm{~h}$, a reduction of only 0.03 was recorded.

The behaviour of the model differs since the moisture content represents the average value of the entire soil layer. Its drainage is controlled by the small exfiltration rate (no underdrain) thus the soil layer remains saturated for some time. A reduction of up to 0.11 in the moisture content was reported in the simulation after a $24 \mathrm{~h}$ period.

The data in Figure 15(b) presents a lower moisture content in the model before the rainfall. This could indicate that the exfiltration rate in the field is much less than $2.6 \mathrm{~mm} / \mathrm{h}$. Another possibility is that the field measurements do not consider locations where the conductivity is higher (e.g. preferential pathways through the soil).

The field data indicate the soil can partially recover its storage capacity immediately after an event and not remain completely saturated. Assuming that the same behavior occurred for event 2 would explain there being no outflow measured in the field data after the largest peak in Figure 14(a).

In Figure 15(a), although the second rainfall peak has a much lower intensity, the soil has reached saturation in the model, preventing any storage; this results in two similar outflow peaks. The variation in the intensity of the rainfall peaks is captured more accurately in the measured outflow data. The main inconsistency in the measured vs simulated outflow is due to the inability of the model to predict the soil recovery capacity between consecutive peaks.

The calibrated model predicts accumulation inside the trapezoidal channel (presented in Figure 7) due to the regulator for events 3, 4 and 5 which have high average intensities (short durations). Nevertheless, the backwater is drained quickly (in $\sim 20$ min); applying a seepage rate to the channel does not affect the outflow hydrographs. The backing up of flow in the channel does not appear to affect the results in any significant manner.

In the case of the bioretention basin, the factor dominating the prediction of outflow is whether the level in the storage layer has reached the drain offset height (herein $200 \mathrm{~mm}$ ). Once attained, the percolating water starts flowing out from the drain and the moisture level in the soil begins to decrease, only increasing if additional rainfall occurs. A long or low intensity event (such as event 2) composed of multiple small peaks in succession will cause both the soil moisture content and storage layer level to rise prior to the largest rainfall peak as presented in Figure 16(b).

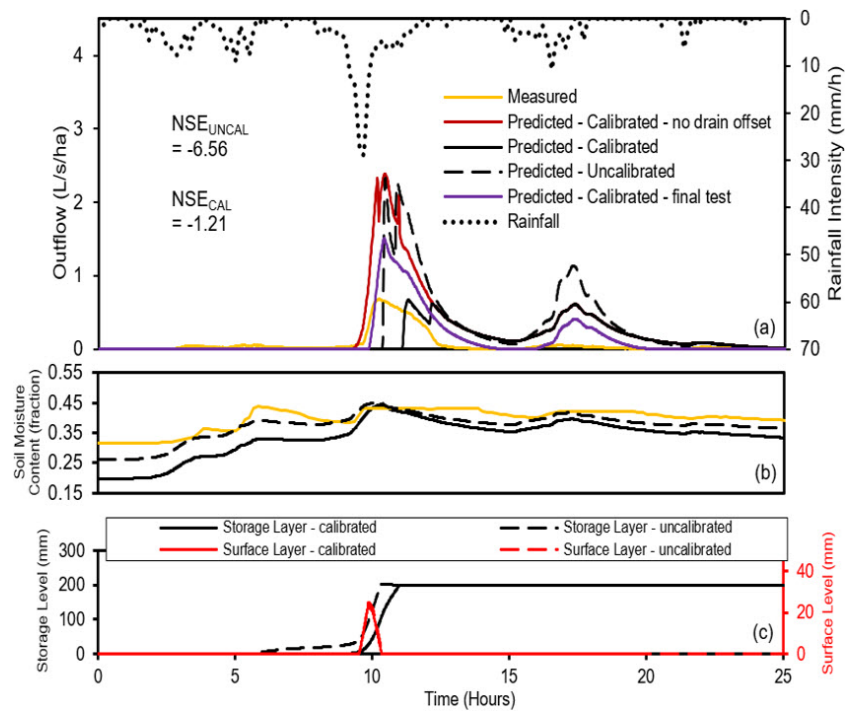

Figure 16 Comparison between (a) measured and simulated outflow hydrographs (L/s/ha of impervious catchment),

(b) measured and simulated soil moisture content and

(c) simulated storage and surface layer levels in the bioretention basin for significant event 2 .

A short or high intensity event (event 5), with no rainfall prior to the peak intensity and thus an empty storage layer, will have a longer delay in the timing of the predicted outflow peak. A larger portion of the inflow will be temporarily stored at the surface, as seen in Figure 17(c).

For both events 2 and 5, the measured outflow begins when there is a distinct plateau in the field moisture content data (saturation). The outflow peak occurs $\sim 25$ min after the peak rainfall intensity. This contrasts with the model where the outflow peak of event 5 occurs $1 \mathrm{~h}$ after the outflow peak for event 2 . Additionally, for event 5 , the soil becomes saturated 35 min prior to the outflow beginning.

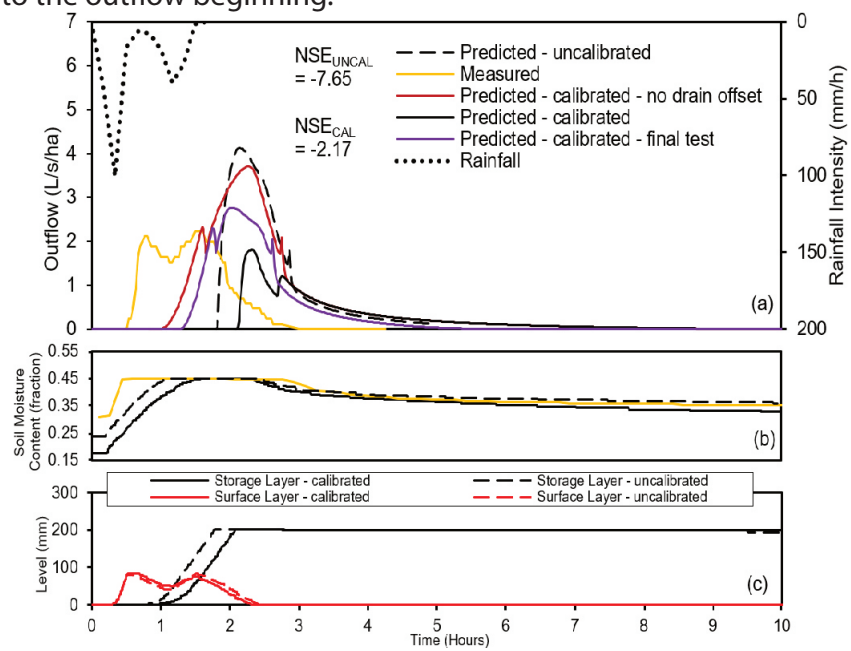

Figure 17 Comparison between (a) measured and simulated outflow hydrographs (L/s/ha of impervious catchment), (b) measured and simulated soil moisture content and (c) simulated storage and surface layer levels in the bioretention basin for significant event 5 . 
The model is reacting more precisely to the differences in rainfall event characteristics and predicting the delay in the peak that is expected to occur (on the order of $1 \mathrm{~h}$ or more). This is not the case for the field data which could indicate that during a high intensity event, the flow takes preferential pathways in the soil that would enable a storage layer bypass.

Running the calibrated model with a storage layer depth of $200 \mathrm{~mm}$ and a drain offset of zero results in a significant overestimation of the outflow volume and peak but an improvement in the timing of the outflow (Figures 16(a) and 17(a)). It is possible that, in the field, only a portion of the flow is exiting through the preferential paths, enabling the structure to retain a large portion of runoff. This remains uncertain since no field data was collected which can confirm the hypothesis.

There remain two parameters which can aid in reducing the volume and peak: the seepage rate in the LID Control and the evaporation rates. These were tested by doubling both values in the model. The seepage rate was increased from $2.6 \mathrm{~mm} / \mathrm{h}$ to 5.6 $\mathrm{mm} / \mathrm{h}$ and the evaporation rates were increased from $0 \mathrm{~mm} / \mathrm{d}$, $4.2 \mathrm{~mm} / \mathrm{d}, 4.6 \mathrm{~mm} / \mathrm{d}$ and $4.6 \mathrm{~mm} / \mathrm{d}$ to $4 \mathrm{~mm} / \mathrm{d}, 8.4 \mathrm{~mm} / \mathrm{d}, 9.2$ $\mathrm{mm} / \mathrm{d}$ and $9.2 \mathrm{~mm} / \mathrm{d}$ for April, May, June and July respectively. An example of these results is presented in Figures 16(a) and 17(a) to demonstrate that it remains difficult to have the predicted outflow occur at the same time as the measured outflow without having an overestimation of the volume which requires an exaggeration of certain parameter values to be rectified.

A final element was tested to understand the influence of the regulator on the model. The outflow rate is controlled by the head of water behind the regulator. In the field, it is possible for the accumulated water in the junction connecting the LID and regulator to backup into the LID cell through the underdrain. In fact, the height behind the regulator will be influenced by the level within the entire LID unit and not just at the junction. This relationship is not considered when modeling LID Controls. It is not possible for the junction to communicate back to the LID Control subcatchment. In order to connect the two, the junction was replaced with a storage unit with the same volume as the actual storage layer. This prevents the outflow volume from simply filling up the junction which could exaggerate the outflow rate. Finally, this design did not have a very significant effect on the results. Nevertheless, in certain cases the peak was reduced, and the curves were smoother.

Considering all events, three different types of issue were identified: volume overestimation, difference in the shape of the hydrographs and misalignment in time. Thus, the reasons for the difference between the simulated and observed data were not consistent. When calibrating, alterations in either the input parameters or the design of the structure can reduce the error for some events but increase it for others, consistently culminating in a negative global NSE. Therefore it is necessary in the case of the bioretention basin to have a variety of calibration parameter sets for specific categories of rainfall events.

\section{Conclusion}

LID microstructures represent viable solutions to lessen the impacts of urban development through the infiltration of stormwater runoff into the ground. Hydrologic models can be used to aid the implementation of such systems in the urban landscape. It is necessary to ensure the LID solution is accurately represented in the model.

In this project, the soil layer of the constructed cells has a trapezoidal cross section in contrast with the rectangular cross section assumed by SWMM. In the final calibration, the soil section was split in two and the topsoil filling the sides of the trapezoid was represented by a general pervious subcatchment. The runoff from the adjacent sidewalk was routed onto this topsoil layer which was then routed to the main LID Control subcatchment. The main consequence of this alteration was a reduction in the volume of inflow, since any flow infiltrating into the pervious subcatchment would not reach the main LID Control. This proved beneficial for both structures since the model was initially significantly overestimating the outflow volume and peak flows. Nevertheless, this aspect of the modeling did not prove to be the main cause of error between the measured and predicted results.

The predictions of the model were improved by considering parameters with the most influence on the outflow. The conductivity of the pervious surfaces draining into the LID structures was doubled to further reduce the inflow. In order to improve the liberation of the storage capacity of the structures during dry periods, the conductivity slope of the soil (HCO) was reduced from 44 to 35 for the VS and from 44 to 30 for the BB. The hydraulic conductivity of the VS soil was increased from 91 to 120 $\mathrm{mm} / \mathrm{h}$; this parameter had minimal effects on the performance of the bioretention basin.

Although the vegetated swale calibration did produce globally positive results (NSE $=0.64,>0.5$ ), an event based analysis showed that this was not consistent for all events. Of the 47 successfully measured events, 35 produced measured outflows but only 6 were simulated by the model (the largest events of the study). Of these significant events, 2 had NSE $>0.5$. The main issue in the model predictions was for smaller peaks that followed a large peak during an event. The field data showed a capacity of the soil to withhold the runoff from the smaller peaks whereas the soil in the model remained saturated, producing outflow. Therefore, for events with NSE $<0.5$, the model had properly predicted the first peak but overestimated the outflow from the following peaks. This error was seen in events with long durations and many consecutive peaks. In summary, the model optimization presented herein was deemed most accurate for large events with a short duration.

The main difference between the model predictions and the measured data for BB was seen in the behavior of the storage layer which controls the outflow from the structure. The variations in the time required to fill the storage layer depending on the event was not reflected in the measured data leading to the 
predicted outflow occurring on average $1 \mathrm{~h}$ after the measured. Attempts to rectify this error led to an overestimation of the outflow volume and peak. It was hypothesized that during events with high intensity, a portion of the flow was bypassing the filling of the storage layer through preferential flow pathways.

Finally, a larger dataset would strengthen the accuracy of the model predictions and permit the development of multiple parameter optimization sets specific to different categories of events.

\section{Acknowledgments}

This research was funded by the City of Montreal. Additional significant contributors are Étienne Bélanger and Alexandra Maisonneuve who completed the field work. Evelyne Pouliot and Mariam Sylla aided with data collection, processing and validation. Carl Gagnon-Ouellette (Junior Engineer at EXP) provided a lot of insight into the functioning of PCSWMM and helped greatly with the provision of ideas to include in the discussion sections.

\section{References}

ASTM D5242-92. 2013. Standard Test Method for Open-Channel Flow Measurement of Water with Thin-Plate Weirs. West Conshohocken, PA: ASTM International.

Brière, G.F. 2007. Drinking-Water Distribution, Sewage, and Rainfall Collection, 2nd ed. Montreal: Polytechnique International Press.

Burszta-Adamiak, Ewa, and Maciej Mrowiec. 2013. "Modeling of Green Roofs' Hydrological Performance using EPA's SWMM." Water Science and Technology 68 (1): 36-42.

Davis, Allen P. 2008. “Field Performance of Bioretention: Hydrology Impacts." Journal of Hydrologic Engineering 13 (2): 90-5.

Davis, Allen P., William F. Hunt, Robert G. Traver, and Michael Clar. 2009. "Bioretention Technology: Overview of Current Practice and Future Needs." Journal of Environmental Engineering 135 (3): 109-17.

DeBusk, Kathy M., William F. Hunt, and Daniel E. Line. 2010. “Bioretention Outflow: Does it Mimic Nonurban Watershed Shallow Interflow?" Journal of Hydrologic Engineering 16 (3): 274-9.

Deletic, Ana, and Tim D. Fletcher. 2006. “Performance of Grass Filters used for Stormwater Treatment-A Field and Modeling Study." Journal of Hydrology 317 (3-4): 261-75.

Dietz, Michael E. 2007. “Low Impact Development Practices: A Review of Current Research and Recommendations for Future Directions." Water, Air, Soil Pollution 186 (1-4): 351-63.

Dietz, Michael E., and John C. Clausen. 2005. “A Field Evaluation of Rain Garden Flow and Pollutant Treatment." Water, Air, Soil Pollution 167 (1-4): 123-38.

Eckart, Kyle, Zach McPhee, and Tirupati Bolisetti. 2017. “Performance and Implementation of Low Impact DevelopmentA Review." Science of the Total Environment 607: 413-32.
Elliott, A.H., and Sam A. Trowsdale. 2007. "A Review of Models for Low Impact Urban Stormwater Drainage." Environmental Modeling Software 22 (3): 394-405.

Engel, Bernard, Dan Storm, Mike White, Jeff Arnold, and Mazdak Arabi. 2007. “A Hydrologic/Water Quality Model Applicati1 1." JAWRA Journal of the American Water Resources Association 43 (5): 1223-6.

Environment Canada. 2018. Données des stations pour le calcul des normales climatiques au Canada de 1981 à 2010 Montréal/Pierre Elliott Trudeau Intl A - Évaporation. Ottawa: Environment Canada.

https://climat.meteo.gc.ca/climate_normals/ results_1981_2010_f.html?searchType=stnNam e\&txtStationName=Montr\%C3\%A9al\&searchM ethod=contains\&txtCentralLatMin $=0 \&$ txtCentra ILatSec $=0$ \&txtCentralLongMin $=0 \&$ txtCentralLongSec $=0 \& \operatorname{stn} I D=5415 \&$ dispBack $=0$

Ewing, Sarah A, Rodger B. Grayson, and Robert M. Argent. 2000. "Science, Citizens, and Catchments: Decision Support for Catchment Planning in Australia." Society \& Natural Resources 13 (5): 443-59.

Fassman, Elizabeth, and Karen Stokes. 2011. “Media Moisture Content to Determine Evapotranspiration from Swales and Bioretention Cells." World Environmental and Water Resources Congress 2011: Bearing Knowledge for Sustainability.

Fuamba, Musandji, Flora Branger, Isabelle Braud, Essoyeke Batchabani, Pedro Sanzana, Benoit Sarrazin, and Sonja Jankowfsky. 2019. "Value of Distributed Water Level and Soil Moisture Data in the Evaluation of a Distributed Hydrological Model: Application to the PUMMA Model in the Mercier Catchment $\left(6.6 \mathrm{~km}^{2}\right)$ in France." Journal of Hydrology 569: 753-70.

García-Gaines, R., and S. Frankenstein. 2015. USCS and the USDA Soil Classification System: Development of a Mapping Scheme. Vicksburg, MS: U.S. Army Engineer Research and Development Center, Cold Regions Research and Engineering Laboratory.

lowa Stormwater Partnership. 2008. Rain Gardens: Iowa Rain Garden Design and Installation Manual. Ames, IA: lowa Department of Agriculture.

https://www.iowaagriculture.gov/press/pdfs/RainGardenManual.pdf

James, W. 2005. Rules for Responsible Modeling. Guelph: CHI.

James, William, E. Lewis Rossman and C. Robert W. James. 2011. User's Guide to SWMM. Guelph: CHI.

Jewell, Thomas K. Donald Dean Adrian and Thomas J. Nunno. 1978. "Methodology for Calibrating Stormwater Models." Journal of the Environmental Engineering Division 104 (3): 485-501.

Lee, Joong Gwang, Christopher T. Nietch and Srinivas Panguluri. 2018. “Drainage Area Characterization for Evaluating Green 
Infrastructure using the Storm Water Management Model." Hydrology Earth System Sciences 22 (5): 2615-35.

Les Services EXP Inc. 2019. Rapport d'analyse hydraulique-Aménagement complet.

Mailhot, Alain, and Guillaume Talbot. 2012. Courbe IDFMontreal-Pierre Elliot Trudeau Intl A. Quebec: Atlas agroclimatique du Quebec.

http://www.agrometeo.org/atlas/idf_station/MONTREALPIERRE_ELLIOTT_TRUDEAU_INTL_A/Montr\%C3\%A9alPierre\%20Elliot\%20Trudeau\%20 Intl\%20A/7025250/false

McCutcheon, Matthew, and Derek Wride. 2013. "Shades of Green: Using SWMM LID Controls to Simulate Green Infrastructure." Journal of Water Management Modeling 21: R246-15. https://doi.org/10.14796/JWMM.R246-15

MDDEFP. 2014. Guide de gestion des eaux pluviales. Quebec: Ministère de l'Environnement et de la Lutte contre les change-ments climatiques. http://www.environnement.gouv.qc.ca/eau/pluvia-les/ guide.htm

Nash, J. E., and J. V. Sutcliffe. 1970. “River Forecasting using Conceptual Models, 1: A Discussion of Principles." Journal of Hydrology 10: 280-90.

Niazi, M., C. Nietch, M. Maghrebi, N. Jackson, B.R. Bennett, M. Tryby, and A. Massoudieh. 2017. "Stormwater Management Model: Performance Review and Gap Analysis." Journal of Sustainable Water in the Built Environment 3 (2): 04017002.

Peng, Zhangjie, and Virginia Stovin. 2017."Independent Validation of the SWMM Green Roof Module." Journal of Hydrologic Engineering 22 (9): 04017037.

PGCo (The Prince George's County). 2007. Bioretention Manual. The Prince George's County, MD: Environmental Services Division, Department of Environmental Resources. https://www.aacounty.org/departments/public-works/ highways/forms-and-publications/RG_Bioretention_ PG\%20CO.pdf

Ramanarayanan, T.S., J.R. Williams, W.A. Dugas, L.M. Hauck, and A.M.S. McFarland. 1997. “Using APEX to Identify Alternative Practices for Animal Waste Management." ASAE Paper.

Rosa, David J., John C. Clausen, and Michael E. Dietz. 2015. "Calibration and Verification of SWMM for Low Impact Development." JAWRA Journal of the American Water Resources Association 51 (3): 746-57.

Rossman, L.A. 2015. Storm Water Management Model User's Manual Version 5.1. Cincinnati, OH: U.S. Environmental Protection Agency.

Rossman, L., and W. Huber. 2016a. Storm Water Management Model Reference Manual Volume I, Hydrology. Washington, DC: U.S. Environmental Protection Agency Office of Research and Development.

Rossman, L., and W. Huber. 2016b. Storm Water Management Model Reference Manual Volume III-Water Quality.
Washington, DC: U.S. Environmental Protection Agency Office of Research and Development.

Rushton, Betty T. 2001. “Low-Impact Parking Lot Design Reduces Runoff and Pollutant Loads." Journal of Water Resources Planning and Management 127 (3): 172-9.

Santhi, C., Jeffrey G. Arnold, Jimmy R. Williams, William A. Dugas, Raghavan Srinivasan, and Larry M. Hauck. 2001.

"Validation of the SWAT Model on a Large River Basin with Point and Nonpoint Sources 1." JAWRA Journal of the American Water Resources Association 37 (5): 1169-88.

Shamsi, Uzair M. 2012. “Modeling Rain Garden LID Impacts on Sewer Overflows." Journal of Water Management Modeling 20: R245-07. https://doi.org/10.14796/JWMM.R245-07

Shamsi, Uzair M., and Joseph Koran. 2017. “Continuous Calibration." Journal of Water Management Modeling 25: C414. https://doi.org/ 10.14796/JWMM.C414

Stovin, Virginia R., Sarah L. Moore, Matthew Wall, and Richard M. Ashley. 2013. “The Potential to Retrofit Sustainable Drainage Systems to Address Combined Sewer Overflow Discharges in the Thames Tideway Catchment." Water Environment Journal 27 (2): 216-28.

Teledyne ISCO. 2016. 2150 Area Velocity Flow Module and Sensor, Installation and Operation Guide. Lincoln, NE: Teledyne ISCO.

USEPA (U.S. Environmental Protection Agency). 1983. Final Report of the Nationwide Urban Runoff Program (NURP). Washington, DC: U.S. Environmental Protection Agency.

USEPA (U.S. Environmental Protection Agency). 1999a. Combined Sewer Overflows Guidance For Monitoring and Modeling. Washington, DC: U.S. Environmental Protection Agency.

USEPA (U.S. Environmental Protection Agency). 1999b. Storm Water Technology Fact Sheet-Bioretentio. Washington, DC: U.S. Environmental Protection Agency.

Veolia Water Technologies. 2014. HYDROVEX ${ }^{\circledR}$ VHV/SVHV Vertical Vortex Flow Regulator CSO, SSO, Stormwater Management. Accessed September 2020. http://technomaps.veoliawatertechnologies. com/processes/lib/pdfs/productbrochures/brochures_hydrovex/1928,Hydrovex-VHV-SVHV-VerticalVortex-F.pdf

WCI Physics. n.d. "The Burns Guide to Uncertainties and Error Propagation." Minnetonka, MN: Burns Engineering. http://www.mjburns.net/SPH4U/Burns\%20Error\%20 Analysis\%20techniques.pdf

Zhao, Dongquan, Jining Chen, Haozheng Wang, Qingyuan Tong, Shangbing Cao, and Zheng Sheng. 2009. "GIS-Based Urban Rainfall-Runoff Modeling using an Automatic Catch-ment-Discretization Approach: A Case Study in Macau." Environmental Earth Sciences 59 (2): 465. 